To the Editors:

\title{
A pilot study on CYP21 gene deletions among a cohort of Sri Lankan children with congenital adrenal hyperplasia
}

\author{
D K Jayathilaka ${ }^{1}$, K H Tennekoon ${ }^{1}$, K S H de Silva², S De Silva ${ }^{1}$ \\ Ceylon Medical Journal 2017; 62: 112-113 \\ DOI: http://doi.org/10.4038/cmj.v62i2.8479
}

Deficiency of steroidogenic enzymes in the adrenal cortex results in a group of genetic disorders known as congenital adrenal hyperplasia (CAH). The diagnosis is based on clinical features and confirmed by appropriate biochemical investigations and ultrasound findings. The inherited inability to synthesize cortisol in CAH is due to deficiency of several enzymes required for cortisol synthesis [1]. The most frequent is 21-hydroxylase deficiency, accounting for more than $90 \%$ of cases [2].

Mutations in the CYP21 gene encoding for 21hydroxylase enzyme correlate with different levels of enzymatic compromise and therefore manifest different degrees of clinical severity of the disease. Approximately $20 \%$ of these mutations are meiotic recombinations that delete a $30 \mathrm{~kb}$ gene segment rendering total ablation of the enzyme activity that in turn cause inability to preserve sodium as seen in salt wasters [3].

Measurement of a steroid precursor, 17-hydroxyprogesterone is used in neonatal screening for CAH to detect 21-hydroxylase deficiency. But pitfalls complicate the use of hormonal screening as a variety of other inborn metabolic errors are also associated with similar fluctuations of this precursor [4]. Therefore, the aim of this study was to investigate the possible presence of large gene deletions in a cohort of patients with the salt wasting form of $\mathrm{CAH}$ so that genetic testing can be instituted to confirm the diagnosis based on clinical features and biochemical assays. This is the first report from Sri Lanka documenting the presence of large gene deletions in the CYP21 gene in a cohort of patients with $\mathrm{CAH}$.

Ethical clearance (EC-15-050) was obtained from the Ethics Review Committee of the Faculty of Medicine,
University of Colombo. Twenty one CAH patients presenting to a ward at the Lady Ridgeway Hospital, Colombo and clinically diagnosed and confirmed with the available laboratory and radiological facilities as salt wasters were invited to participate in the study. Written informed consent was obtained from parents/guardians and those who did not give consent were excluded from the study. Peripheral venous blood (2 ml) was obtained for DNA extraction.

Quantified genomic DNA was subjected to Multiplex ligation-dependent probe amplification (MLPA) assay to detect possible large gene rearrangements in the CYP21 gene using SALSA MLPA KIT P050-C1 CAH probemix (MRC-Holland, Amsterdam, Netherlands) according to manufacturer's protocol. Fragment separation was carried out on an ABI 3500(Dx) Series Genetic Analyzer (Applied Biosystems, Foster City, CA). Coffalyser. Net software was used for statistical evaluation of all normalized data and the relative amount of fluorescence related to each probe expressed as dosage quotients or probe ratios were calculated.

Patients studied were from 20 families with one pair of siblings. Two were born to consanguineous parents. Characteristics of the study population are given in Table1.

MLPA analysis revealed that five patients (24\%; four females and one male) had large gene deletions in the CYP21 gene. They were products of non-consanguineous unions. Being salt wasters, at presentation they had clinical and biochemical evidence of deficiency of cortisol and aldosterone. Four index patients were Sinhalese and one a Sri Lankan Tamil. Four had large gene aberrations extending from exons 1 to 7 in the CYP21 gene. Three were heterozygous for the deletions. MLPA

${ }^{1}$ Institute of Biochemistry, Molecular Biology and Biotechnology, University of Colombo and ${ }^{2}$ Department of Paediatrics, Faculty of Medicine, University of Colombo, Sri Lanka.

Correspondence: DKJ, e-mail: <dhananjijayathilaka@gmail.com>. Received 27 December 2016 and revised version accepted 17 March 2017.

This is an open-access article distributed under the terms of the Creative Commons Attribution License, which permits unrestricted use, distribution, and reproduction in any medium, provided the original author and source are credited. 
Table 1. Demographic characteristics of study participants $\mathrm{n}=\mathbf{2 1}$

\begin{tabular}{|c|c|}
\hline & $\begin{array}{c}\text { No of patients } \\
(n=21)\end{array}$ \\
\hline \multicolumn{2}{|l|}{ Age at presentation } \\
\hline $1^{\text {st }}$ month & 11 \\
\hline $2^{\text {nd }}$ month- $6^{\text {th }}$ months & 03 \\
\hline $7^{\text {th }}$ month $-12^{\text {th }}$ month & 01 \\
\hline 1 year-7 years & 06 \\
\hline \multicolumn{2}{|l|}{ Age at study (years) } \\
\hline $1-5$ & 05 \\
\hline $6-10$ & 12 \\
\hline $11-15$ & 03 \\
\hline $16-20$ & 01 \\
\hline \multicolumn{2}{|l|}{ Gender } \\
\hline Female & 14 \\
\hline Male & 7 \\
\hline \multicolumn{2}{|l|}{ Ethnicity } \\
\hline Sinhalese & 17 \\
\hline Sri Lankan Tamil & 01 \\
\hline Moor & 03 \\
\hline \multicolumn{2}{|l|}{ Province of residence } \\
\hline Western & 11 \\
\hline Sabaragamuwa & 05 \\
\hline North Central & 02 \\
\hline Central & 01 \\
\hline North & 01 \\
\hline North Western & 01 \\
\hline
\end{tabular}

result of one of these patients is given in Figure 1. The fourth patient had a deletion homozygous from exons 1 to 3, and heterozygous from exons 4 to 7 (Figure 2, supplementary file). The fifth patient positive for large gene deletions had a heterozygous deletion extending from exons 3 to 7 (Figure 3, supplementary file).

Five patients $(23.80 \%)$ in the present study had reduction of genomic dosages (deletions) in the CYP21 gene and of them four were heterozygous. CAH is an autosomal recessive disorder. One allele remaining in the homologous chromosome pair of these four patients may carry different disease causing mutations as seen in compound heterozygotes. In compound heterozygosity there are two heterozygous recessive alleles at a particular locus with both alleles harboring different mutations.
CAH patients are usually compound heterozygotes for different mutations [1]. Patients with severe mutations are reported to have impaired enzyme activity irrespective of whether they are homozygous or heterozygous for the mutation [5]. Thus in the four heterozygous patients in the present study, residual enzyme activity would not have been sufficient enough to prevent salt wasting manifestations.

Aetiology of enzyme deficiency in the patient who had a homozygous exon deletion (exon 1 to exon 3 ) is clear. Production of 21-hydroxylase enzyme may be hampered to a considerable level in this patient thus reducing mineralocorticoids. Patients who were heterozygous in the present study may have unique combinations of alleles resulting in different residual enzyme activity in vivo. Other sixteen patients in the cohort who did not show copy number alteration might have other changes such as point mutations of the CYP21 gene ablating enzyme activity giving rise to the salt wasting phenotype. Further analysis of the CYP21 gene is needed to identify the underlying genetic cause in them.

\section{Acknowledgement}

We thank Ms. Madusha Jayasundara who assisted in sample collection and DNA extraction.

\section{Conflicts of interest}

There are no conflicts of interest.

\section{References}

1. White PC, Speiser PW. Congenital Adrenal Hyperplasia due to 21-hydroxylase deficiency. Endocr Rev 2000; 21: 245-91.

2. Speiser PW, White PC. Congenital Adrenal Hyperplasia. $N$ Engl J Med 2003; 349: 776-88.

3. White PC, Vitek A, Dupont B, New MI. Characterization of frequent deletions causing steroid 21-hydroxylase deficiency. Proc Natl Acad Sci USA 1988; 85: 4436-40.

4. Speiser PW, White PC. Cogenital adrenal hyperplasia due to 21-hydroxylase deficiency. Clin Endocrinol 1998; 49: 411-7.

5. Forest MG. Recent advances in the diagnosis and management of congenital adrenal hyperplasia due to 21hydroxylase. Hum Reprod Update 2004; 10: 469-85. 